\title{
HUBUNGAN POLA ASUH ORANG TUA DENGAN PERKEMBANGAN KEMANDIRIAN MENGONTROL BUANG AIR BESAR DAN BUANG AIR KECIL PADA ANAK USIA 3 TAHUN DI DESA JATISARI KECAMATAN JAKENAN KABUPATEN PATI TAHUN 2012
}

\author{
Murni Asih Arining Tyas ${ }^{1)}$, Uswatun Kasanah ${ }^{2)}$, Nopri Padma Nudesti ${ }^{3)}$ \\ ${ }^{1}$ Sekolah Tinggi Ilmu Kesehatan Bakti Utama Pati \\ ${ }^{2}$ Sekolah Tinggi Ilmu Kesehatan Bakti Utama Pati \\ ${ }^{3}$ Sekolah Tinggi Ilmu Kesehatan Bakti Utama Pati \\ Email: haqqacantiq@stikesbup.ac.id
}

\begin{abstract}
ABSTRAK
Pola asuh merupakan sikap orang tua dalam berinteraksi dengan anak-anaknya. Periode penting dalam tumbuh kembang anak adalah masa balita. Karena pada masa ini pertumbuhan dasar akan mempengaruhi dan menentukan perkembangan anak selanjutnya. Salah satu stimulasi yang penting dilakukan orangtua adalah stimulasi terhadap kemandirian anak dalam melakukan BAB (Buang Air Besar) dan BAK (Buang Air Kecil).

Perumusan masalah dalam penelitian ini adalah Apakah ada Hubungan Tingkat Pola Asuh Orang Tua Dengan Perkembangan Kemandirian Mengontrol BAB dan BAK Pada Anak Usia 3 Tahun Di Desa Jatisari Kecamatan Jakenan Kabupaten Pati Tahun 2012.

Metode penelitian yang digunakan adalah survey dengan Cross-Sectional. Populasi dalam penelitian ini adalah seluruh ibu yang mempunyai balita berumur 3 tahun di Desa Jatisari Kecamatan Jakenan Kabupaten Pati

Responden di Desa Jatisari Kecamatan Jakenan Kabupaten Pati sebagian besar mempunyai pola asuh yang autoritatif sebanyak 54 orang $(79,4 \%)$ dan paling sedikit mempunyai pola asuh otoritatif sebanyak 4 orang $(5,9 \%)$. Responden di Desa Jatisari Kecamatan Jakenan Kabupaten Pati sebagian besar mempunyai kemandirian yang baik sebanyak 41 orang $(60,3 \%)$ dan yang mempunyai kemandirian tidak baik sebanyak 27 orang $(39,7 \%)$. Ada hubungan antara pola asuh dengan kemandirian mengontrol BAB dan BAK pada anak usia 3 tahun di Desa Jatisari Kecamatan Jakenan Kabupaten Pati (p value 0,009 < 0,05).
\end{abstract}

Kata kunci : Pola asuh orang tua, BAB, BAK pada anak usia 3 tahun

\section{ABSTRACT}

Parenting is the attitude of parents in interacting with their children. An important period in child development is the toddler period. Because at this time basic growth will influence and determine the next child's development. One of the stimulation that is important for parents to do is stimulation of the child's independence in defecating and defecating.

The formulation of the problem in this study is whether there is a relationship between the level of parenting and the development of independence in controlling defecation and childbearing in children aged 3 years in Jatisari Village, Jakenan District, Pati Regency in 2012.

The research method used was a cross-sectional survey. The population in this study were all mothers who have children aged 3 years in Jatisari Village, Jakenan District, Pati Regency

Most of the respondents in Jatisari Village, Jakenan District, Pati Regency, mostly have authoritative parenting as many as 54 people (79.4\%) and at least 4 people (5.9\%) have authoritative parenting. Respondents in Jatisari Village, Jakenan District, Pati Regency, mostly had good independence as many as 41 people (60.3\%) and those who had poor independence were 27 people (39.7\%). There is a relationship between parenting style and independence to control defecation and childbearing in children aged 3 years in Jatisari Village, Jakenan District, Pati Regency ( $p$ value $0.009<0.05$ ).

Keywords: Parenting style, defecation, childbearing age 3 year

\section{PENDAHULUAN}

Anak tumbuh dan berkembang di bawah asuhan orang tua. Melalui orang tua, anak beradaptasi dengan lingkungannya dan mengenal dunia sekitarnya serta pola pergaulan hidup yang berlaku di lingkungannya. Ini disebabkan oleh orang tua merupakan dasar pertama bagi pembentukan pribadi anak (Tarmizi, 2009).

Peran aktif orang tua terhadap perkembangan anak-anaknya sangat 
diperlukan terutama pada saat mereka masih dibawah lima tahun (balita). Setelah kita mengetahui peran aktif orang tua terhadap perkembangan anak, maka alangkah baiknya bila kita mengetahui bagaimana sikap orang tua dalam keluarga dan kemungkinan akibatnya yang akan timbul bagi perkembangan anak (Surviana, 2005).

Memang tidak mudah untuk mengetahui masalah yang berdampak besar dalam perkembangan diri seorang anak. Mungkin setiap anak mempunyai masalah yang berbeda-beda. Kemungkinan adanya sikap menyerah terhadap kesulitan tergantung dari reaksi orangtuanya (Julaihah, 2004).

Pola asuh merupakan sikap orang tua dalam berinteraksi dengan anakanaknya. Sikap tersebut meliputi cara orangtua memberikan aturan-aturan, memberikan perhatian. Pola asuh sebagai suatu perlakuakn orangtua dalam rangka memenuhi kebutuhan, memberi perlindungan dan mendidik anak dalam kesehariannya. Sedangkan Pengertian pola asuh orangtua terhadap anak merupakan bentuk interaksi antara anak dan orangtua selama mengadakan pengasuhan yang berarti orangtua mendidik, membimbing dan melindungi anak (Soetjiningsih, 2002).

Pertumbuhan dan perkembangan merupakan dua peristiwa yang sangat berbeda tetapi saling berkaitan dan sulit dipisahkan. Pertumbuhan mempunyai dampak terhadap aspek fisik anak sedangkan perkembangan berkaitan dengan pematangan fungsi organ atau individu (Ngastiyah, 2005).

Periode penting dalam tumbuh kembang anak adalah masa balita. Karena pada masa ini pertumbuhan dasar akan mempengaruhi dan menentukan perkembangan anak selanjutnya. Pada masa balita ini perkembangan kemampuan berbahasa, kreativitas, kesadaran sosial, emosional dan intelegensia berjalan sangat cepat dan merupakan landasan perkembangan berikutnya. Perkembangan moral serta dasar-dasar kepribadian juga dibentuk pada masa ini, sehingga setiap kelainan atau penyimpangan sekecil apapun apabila tidak terdeteksi apalagi tidak ditangani dengan baik akan mengurangi kualitas sumber daya manusia kelak (Soetjiningsih, 2002).

Perkembangan seorang anak secara umum dipengaruhi oleh dua faktor utama, yaitu faktor genetik dan faktor lingkungan. Seorang anak dapat mengembangkan berbagai kecerdasan atas dasar keturunan dengan rangsangan terus menerus dari lingkungan sekitarnya (Surviana, 2005). Salah satu faktor lingkungan yang mempengaruhi proses perkembangan adalah interaksi antara anak dengan orang tuanya khususnya ibu, karena ibu merupakan lingkungan yang pertama dan utama bagi seorang anak usia balita. Peran seorang ibu dalam pengasuhan dapat memberikan motivasi pada anaknya untuk berkembang.

Untuk mencapai tumbuh kembang yang optimal, kebutuhan dasar seorang anak harus terpenuhi, meliputi kebutuhan fisik, kebutuhan sosial atau kasih sayang, dan kebutuhan stimulasi atau pendidikan (Soetjiningsih, 2002). Dalam perkembangan anak terdapat masa krisis, di mana diperlukan rangsangan atau stimulasi yang berguna agar potensi yang dimiliki anak berkembang. Semakin dini dan semakin lama stimulasi diberikan maka semakin besar manfaatnya. Bila stimulasi dalam interaksi sehari-hari kurang maka perkembangan kecerdasannya juga kurang (Soedjatmiko, 2009)

Salah satu stimulasi yang penting dilakukan orangtua adalah stimulasi terhadap kemandirian anak dalam melakukan BAB (Buang Air Besar) dan BAK (Buang Air Kecil). Kebiasaan mengompol pada anak usia di bawah usia 2 tahun masih dianggap sebagai hal yang wajar. Anak mengompol di bawah usia 2 tahun disebabkan karena anak belum mampu mengontrol kandung kemih secara sempurna. Tidak jarang kebiasaan mengompol masih terbawa sampai usia 4-5 tahun. Kasus yang ditemukan di Indonesia anak usia 6 tahun yang masih mengompol sekitar $12 \%$ (Muallifah. 2009).

Mendidik anak dalam melakukan BAB dan BAK akan efektif apabila dilakukan sejak dini. Kebiasaan baik dalam melakukan BAK dan BAB yang dilakukan sejak dini akan dibawa sampai dewasa. Salah satu cara yang dapat dilakukan orangtua dalam mengajarkan BAB dan BAK pada anak adalah melalui toilet training.

Toilet training merupakan cara untuk melatih anak agar bisa mengontrol buang air kecil (BAK) dan buang air besar (BAB). Hal ini penting dilakukan untuk 
melatih kemandirian anak dalam melakukan BAK dan BAB sendiri. Toilet training baik dilakukan sejak dini untuk menanamkan kebiasaan yang baik pada anak (Gilbert, 2003).

Toilet training akan dapat berhasil dengan baik apabila ada kerjasama antara orangtua dengan anak. Kerja sama yang baik akan memberikan rasa saling percaya pada orang tua dan anak. Menurut beberapa penyelidikan, sikap, tingkah laku dan cara berpikir anak kelak setelah ia dewasa akan sangat dipengaruhi pengalamannya pada saat ini. Toilet training sangat penting dalam membentuk karakter anak dan membentuk rasa saling percaya dalam hubungan anak dan orangtua (Eveline \& Nanang, 2010).

Dampak orangtua tidak menerapkan toilet training pada anak diantaranya adalah anak menjadi keras kepala dan susah untuk diatur. Selain itu anak tidak mandiri dan masih membawa kebiasaan mengompol hingga besar. Toilet training yang tidak diajarkan sejak dini akan membuat orangtua semakin sulit untuk mengajarkan pada anak ketika anak bertambah usianya (Hidayat, 2005).

Menurut data dari Susenas (2007) menunjukkan bahwa jumlah balita di Indonesia pada tahun 2007 sekitar 20.851.914 balita (anak usia 0-4 tahun). Jumlah balita di Jawa Tengah terdapat 2.767.378 balita, sedangkan di Kabupaten Semarang sebesar 65.162 anak balita. Menurut Dinas Kesehatan Kabupaten Pati jumlah balita dan anak prasekolah sebanyak 74.575 pada Tahun 2012. Sedangkan di Desa Jatisari Kecamatan Jakenan pada bulan Desember Tahun 2012 terdapat 248 balita dengan umur (3 tahun) sebanyak 83.

Orang tua anak balita di Desa Jatisari Kecamatan Jakenan belum semuanya berhasil melakukan perkembangan dengan mengontrol kemandirian $\mathrm{BAB}$ dan BAK pada anaknya dengan baik. Dalam kegiatan posyandu diketahui banyak balita yang BAB dan BAK dicelana, hal ini menunjukkan kurangnya kemandirian pada anak balita di Desa Jatisari Kecamatan Jakenan.

Berdasarkan hasil survey pada Bulan Oktober 2011 yang telah dilakukan di Desa Jatisari Kecamatan Jakenan Kabupaten Pati menunjukkan bahwa pola asuh autoritatif bisa meningkatkan perkembangan kemandirian mengontrol $\mathrm{BAB}$ dan BAK pada anak. Dilakukan dengan mewawancarai pada 10 orang tua yang mempunyai anak usia 3 tahun didapatkan bahwa ada 3 orang tua yang memiliki pola asuh otoriter dengan perkembangan kemandirian mengontrol BAB dan BAK , 2 orang tua berhasil dan 1 tidak berhasil. Ada 6 orang tua yang memiliki pola asuh autoritatif dengan perkembangan kemandirian mengontrol $\mathrm{BAB}$ dan $\mathrm{BAK}$ berhasil sebanyak 6 orang. Sedangkan ada 1 orang tua yang memiliki pola asuh permisif dengan perkembangan kemandirian mengontrol $\mathrm{BAB}$ dan $\mathrm{BAK}$ tidak berhasil.

Dari uraian di atas maka peneliti ingin melakukan penelitian tentang "Hubungan Tingkat Pola Asuh Orang Tua Dengan Perkembangan Kemandirian Mengontrol BAB Dan BAK Pada Anak Usia 3 Tahun Di Desa Jatisari Kecamatan Jakenan Kabupaten Pati Tahun 2012"

\section{METODE}

Penelitian ini dilakukan untuk menjelaskan hubungan dua variabel yaitu variabel bebas dan variabel terikat. Jenis penelitian ini adalah bersifat deskriptif analitik. Berdasarkan fokus penelitian tersebut, maka metode penelitian yang digunakan adalah survey dengan CrossSectional dimana obyek penelitian pada beberapa populasi yang diamati peneliti pada waktu yang sama. Penulis akan melakukan penelitian yang menjelaskan pola asuh orang tua dengan perkembangan BAB dan BAK pada anak usia 3 tahun Di Desa Jatisari Kecamatan Jakenan Kabupaten Pati Tahun 2012. Populasi dalam penelitian ini adalah seluruh ibu yang mempunyai balita berumur 3 tahun di Desa Jatisari Kecamatan Jakenan Kabupaten Pati Tahun 2012 berjumlah 83 orang. Sampel pada penelitian ini adalah ibu yang memiliki anak usia 3 tahun di Desa Jatisari Sari Kecamatan Jakenan Kabupaten Pati Bulan JanuariFebruari Tahun 2012. Teknik sampling yang digunakan adalah jenis Purposive Sampling, yaitu 68 sampel.

\section{HASIL}

\section{Analisis Univariat}

a. Pola Asuh

Tabel 4.1 
Distribusi Frekuensi Kategori Pola Asuh Ibu Batita di Desa Jatisari Kecamatan Jakenan Kabupaten Pati Tahun 2012

\begin{tabular}{llcc}
\hline No. & \multicolumn{1}{c}{ Pola Asuh } & F & $\%$ \\
\hline 1. & Pola Asuh Otoriter & 4 & 5,9 \\
2. & Pola Asuh Autoritatif & 54 & 79,4 \\
3. & Pola Asuh Permisif & 10 & 14,7 \\
\hline & Jumlah & 68 & 100 \\
\hline
\end{tabular}

Berdasarkan tabel 4.1 di atas diketahui bahwa ibu batita di Desa Jatisari Kecamatan Jakenan Kabupaten Pati sebagian besar mempunyai pola asuh yang autoritatif sebanyak 54 orang $(79,4 \%)$ dan paling sedikit mempunyai pola asuh otoriter

\section{Tabel 4.2}

Distribusi Frekuensi Kemandirian Mengontrol BAB dan BAK pada Anak Usia 3 Tahun di Desa Jatisari Kecamatan Jakenan Kabupaten Pati Tahun 2012.

\begin{tabular}{llcc}
\hline No. & $\begin{array}{c}\text { Kemandirian Mengontrol BAB dan BAK } \\
\text { pada Anak Usia 3 Tahun }\end{array}$ & F & $\%$ \\
\hline 1. & Tidak Baik & 27 & 39,7 \\
2. & Baik & 41 & 60,3 \\
\hline & Jumlah & 68 & 100 \\
\hline
\end{tabular}

Berdasarkan tabel 4.4 di atas diketahui bahwa ibu batita di Desa Jatisari Kecamatan Jakenan Kabupaten Pati sebagian besar mempunyai kemandirian yang baik sebanyak 41 orang $(60,3 \%)$ dan yang mempunyai kemandirian tidak baik

Tabel 4.5 sebanyak 4 orang $(5,9 \%)$.

\section{b. Kemandirian Mengontrol BAB dan BAK pada Anak Usia 3 Tahun}

Tabulasi Silang Antara Pola Asuh dengan Kemandirian Mengontrol BAB dan BAK pada Anak Usia 3 Tahun di Desa Jatisari Kecamatan Jakenan Kabupaten Pati Tahun 2012

\begin{tabular}{|c|c|c|c|c|c|c|c|}
\hline \multirow{3}{*}{ No } & \multirow{3}{*}{ Pola Asuh } & \multicolumn{4}{|c|}{ Kemandirian } & \multirow{2}{*}{\multicolumn{2}{|c|}{ Total }} \\
\hline & & \multicolumn{2}{|c|}{ Tidak Baik } & \multicolumn{2}{|c|}{ Baik } & & \\
\hline & & $\mathrm{F}$ & $\%$ & $\mathrm{f}$ & $\%$ & $\mathrm{f}$ & $\%$ \\
\hline 1. & Pola Asuh Otoriter & 4 & 100 & 0 & 0 & 4 & 100 \\
\hline 2. & Pola Asuh Autoritatif & 17 & 31,5 & 37 & 68,5 & 54 & 100 \\
\hline \multirow[t]{2}{*}{3.} & Pola Asuh Permisif & 6 & 60 & 4 & 40 & 10 & 100 \\
\hline & Jumlah & 27 & 39,7 & 41 & 60,3 & 68 & 100 \\
\hline
\end{tabular}

Berdasarkan Tabel 4.5 di atas menunjukkan bahwa ibu batita di Desa Jatisari Kecamatan Jakenan Kabupaten Pati yang mempunyai pola asuh otoriter sebagian besar mempunyai kemandirian tidak baik sebanyak 4 orang $(100 \%)$ dan tidak ada yang mempunyai kemandirian baik.

Ibu batita di Desa Jatisari Kecamatan sebanyak 27 orang $(39,7 \%)$.

\section{Analisis Bivaria}

a. Hubungan Pola Asuh dengan Kemandirian Mengontrol BAB dan BAK pada Anak Usia 3 Tahun 
mempunyai kemandirian tidak baik sebanyak 6 orang $(60 \%)$ dan mempunyai kemandirian baik sebanyak 4 orang $(40 \%)$.

Untuk membuktikan adanya hubungan antara pola asuh dengan kemandirian mengontrol $\mathrm{BAB}$ dan $\mathrm{BAK}$ pada anak usia 3 tahun di Desa Jatisari Kecamatan Jakenan Kabupaten Pati dilakukan uji statistik yaitu Chi square dengan hasil nilai chi square hitung 9,320> chi square tabel 5,9915 dan $p$ value $0,009<$ 0,05 sehingga Ha diterima dan Ho ditolak, berarti ada hubungan antara pola asuh dengan kemandirian mengontrol $\mathrm{BAB}$ dan BAK pada anak usia 3 tahun di Desa Jatisari Kecamatan Jakenan Kabupaten Pati.

\section{PEMBAHASAN}

\section{Pola Asuh Orang Tua}

Orang tua di Desa Jatisari Kecamatan

Jakenan Kabupaten Pati sebagian besar mempunyai pola asuh yang autoritatif sebanyak 54 orang $(79,4 \%)$ dan yang mempunyai pola asuh otoriter sebanyak 4 orang $(5,9 \%)$.

Orang tua di Desa Jatisari Kecamatan Jakenan Kabupaten Pati sebagian besar mempunyai pola asuh yang autoritatif sebanyak 79,4\%, karena ibu tahu bahwa mengasuh anak harus bijaksana. Anak harus dididik untuk disiplin tetapi juga harus diberikan kepercayaan untuk melakukan kegiatan seperti BAB dan BAK sendiri. Pola asuh autoritatif diharapkan perkembangan anak dapat tumbuh dengan baik dapat mandiri dan tidak tergantung dengan orang lain. Selain itu pendidikan orang tua sebagian besar tamat SMP sehingga mereka tahu bahwa pola asuh yang baik sangat penting untuk membentuk kemandirian anak.

Menurut Baumrind (dalam Muallifah, 2009) berdasarkan hasil pemaparan teori dan model pola asuh yang dikemukakan dari hasil penelitiannya, maka pola pengasuhan yang ideal untuk perkembangan anak adalah pola pengasuhan otoritatif.

2. Kemandirian Mengontrol $\mathrm{BAB}$ dan BAK pada Anak Usia 3 Tahun

Orang tua di Desa Jatisari Kecamatan Jakenan Kabupaten Pati sebagian besar mempunyai kemandirian mengontrol $\mathrm{BAB}$ dan BAK baik sebanyak 41 orang $(60,3 \%)$ dan yang mempunyai kemandirian tidak baik sebanyak 27 orang
$(39,7 \%)$.

Orang tua di Desa Jatisari sebagian besar anaknya mempunyai kemandirian mengontrol $\mathrm{BAB}$ dan $\mathrm{BAK}$ dengan baik sebanyak 60,3\%, karena orang tua menerapkan pola asuh yang baik yaitu dengan menerapkan pola asuh otoritatif. Dengan melakukan pola asuh otoritatif anak lebih bertanggung jawab, memiliki ketenangan diri, adaptif, kreatif, penuh perhatian, terampil secara sosial, dan berhasil di sekolah. Anak tidak tergantung pada orang lain, tidak pasif, dan dapat menyesuaikan diri secara sosial.

Menurut Baumrind (dalam Muallifah, 2009), ada beberapa cap untuk orang tua, yaitu :

1) Dalam pendidikan keluarga yang mempunyai sistem indulgent (kesabaran yang tinggi), anak akan lebih cenderung kurang matang, tidak bertanggung jawab, lebih merasa cocok dengan teman sebaya, dan kurang mampu menduduki posisi pimpinan

2) Dalam sistem otoritatif, anak lebih bertanggung jawab, memiliki ketenangan diri, adaptif, kreatif, penuh perhatian, terampil secara sosial, dan berhasil di sekolah.

3) Dalam keluarga otoriter, anak akan menjadi lebih tergantung pada orang lain, lebih tergantung pada orang lain, lebih pasif, dan kurang dapat menyesuaikan diri secara sosial, kurang ketenangan diri, dan kurang perhatian secara intelektual

4) Sedangkan, anak dalam pendidikan indifferent, anak sering implusif, cenderung berlaku agresif.

Berdasarkan pemaparan teori dan model pola asuh yang dikemukakan Baumrind dan hasil penelitian, maka pola pengasuhan yang ideal untuk perkembangan anak adalah pola pengasuhan otoritatif.

3. Hubungan Pola Asuh Orang Tua dengan Perkembangan Kemandirian Mengontrol BAB dan BAK pada Anak Usia 3 Tahun

Hasil penelitian diketahui bahwa ada hubungan antara pola asuh dengan kemandirian mengontrol $\mathrm{BAB}$ dan $\mathrm{BAK}$ pada anak usia 3 tahun di Desa Jatisari Kecamatan Jakenan Kabupaten Pati ( $p$ value 0,009 ). 
Semakin baik penerapan pola asuh orang tua yaitu dengan memperbolehkan putra/putri buang air saat berpergian, tidak memarahi putra/putri setiap kali BAB/BAK (mengompol) dicelana, memberikan pujian setiap kali putra/putri menunjukkan kemajuan seperti bisa cebok sendiri, selalu mendukung jika putra/putri melakukan BAB/BAK ditoilet/kamar mandi maka anak akan merasa percaya diri dan mandiri untuk melakukan BAB sendiri.Anak harus dididik untuk disiplin tetapi juga harus diberikan kepercayaan untuk melakukan kegiatan seperti BAB dan BAK sendiri. Diharapkan dengan pola asuh autoritatif perkembangan anak dapat berkembang dengan baik sehingga anak dapat mandiri dan tidak tergantung dengan orang lain.

Keluarga juga memiliki andil besar terhadap perkembangan anak. Peran aktif orang tua terhadap perkembangan anaknya sangat diperlukan terutama saat mereka masih barada di bawah usia 5 tahun (balita). Peran aktif orang tua terhadap anak dalam mengasuh anak dengan menciptakan lingkungan rumah sebagai lingkungan sosial yang pertama dialami oleh anak sangat penting dalam proses perkembangan. Anak ingin meniru kebiasaan atau kepribadian orang tuanya. Kebutuhan-kebutuhan anak tersebut dapat terpenuhi dalam suatu lingkungan yang merangsang seluruh aspek perkembangan anak (Suherman, 2008).

Pemberian pendidikan sejak dini dengan menerapkan pola asuh yang baik akan mempengaruhi perkembangan otak anak, kesehatan anak, kesiapan anak bersekolah, kehidupan sosial dan ekonomi yang lebih baik di masa depannya. Pola asuh anak yang tepat merupakan fondasi bagi pembelajaran anak, sehingga dapat menjembatani antara kehidupan di rumah dengan kehidupan anak di sekolah (Asmani, 2009).

\section{SIMPULAN DAN SARAN Simpulan}

1. Ibu batita sebagian besar mempunyai pola asuh yang autoritatif sebanyak 54 orang $(79,4 \%)$ dan paling sedikit mempunyai pola asuh otoriter sebanyak 4 orang $(5,9 \%)$.

2. Ibu batita sebagian besar mempunyai kemandirian yang baik sebanyak 41 orang $(60,3 \%)$ dan yang mempunyai kemandirian tidak baik sebanyak 27 orang $(39,7 \%)$.

3. Ada hubungan antara pola asuh dengan kemandirian mengontrol $\mathrm{BAB}$ dan $\mathrm{BAK}$ pada anak usia 3 tahun di Desa Jatisari Kecamatan Jakenan Kabupaten Pati.

\section{Saran}

Masyarakat diharapkan menerapkan pola asuh yang autoritatif dengan memberikan kebebasan pada anak tapi harus bertanggung jawab untuk memenuhi kebutuhannya misalnya kemandirian mengontrol BAB dan BAK. Kepada peneliti lain diharapkan melakukan penelitian tentang faktor lain tentang perkembangan anak misalnya pendidikan usia dini dan permainan edukatif.

\section{DAFTAR PUSTAKA}

Arikunto, Suharsimi. 2006. Prosedur Penelitian. Jakarta: Rineka Cipta

Depkes RI. 2007. Pedoman Pelaksanaan Stimulasi Deteksi dan Intervensi Dini Tumbuh Kembang Di Tingkat Pelayanan Kesehatan Dasar. Depkes RI, Jakarta.

Eveline., \& Nanang, D. 2010. Panduan Pintar Merawat Bayi dan Balita. Jakarta: Wahyu Media

Gilbert, Jane. 2003. Latihan toilet. Jakarta: Erlangga

Julaihah, Elissiti. 2004. Spiritual Parenting. Curiosita

Muallifah. 2009. Psycho Islamic Smart Parenting. Jogjakarta: Diva Press

Ngastiyah. 2005. Perawatan Anak Sakit. EGC, Jakarta

Notoatmodjo, Soekidjo. 2010. Metodologi Penelitian Kesehatan. Jakarta: Rineka Cipta

Soedjatmiko. 2009. Banyak Bermain Bikin Cerdas. (http://www.dr_anak.com

Soetjiningsih. 2002. Tumbuh Kembang Anak. Jakarta : EGC.

Surviana. 2005. Ingin Anak Anda Cerdas dan Kreatif. (http://www.Infoibu.com).

Tarmizi. 2009. Pola Asuh Orang Tua dalam Mengarahkan Perilaku Anak. http://tarmizi.wordpress.com/2009/01/ 26/pola-asuh-orang-tua-dalammengarahkan-perilaku-anak 